\title{
杭の塑性化に着目した遠心載荷実験のシミュレーションに基づいた 大地震時の杭頭損傷評価 \\ DAMAGE EVALUATION OF PILE CAP DURING LARGE EARTHQUAKE BASED ON SIMULATION OF CENTRIFUGAL TEST FOCUSED ON PILE PLASTICITY
}

\author{
柏 尚稔*, 宮本裕司** \\ Hisatoshi KASHIWA and Yuji MIYAMOTO
}

\begin{abstract}
Nonlinear soil-structure interaction effects under strong ground motions should be considered in the seismic design of pile foundation. In order to investigate influence of nonlinear soil-structure interaction, the centrifugal shaking table tests considering the plastic behavior of pile cap are conducted. This paper presents the damage evaluation method of pile cap based on the simulation analysis of the centrifugal shaking table tests, in which the effects of local nonlinearity of pile-soil system on the seismic behavior of pile structures are clarified. The major findings obtained from this study are summarized as follows; 1) The test results are precisely simulated by the 3-dimensional finite element analysis, 2) the slip and separation behavior between the pile and the soil do not affects the seismic behavior of pile structures very much, so the test results are simulated by winklerian model analysis, 3) the plasticity of pile cap emphasizes the influence of the ground displacement subjected to pile on ductility ratio at pile.
\end{abstract}

Keywords :Lateral resistance of pile, Nonlinearity of pile-soil system, Damage evaluation of pile, Simulation analysis of test, 3D-FEM, Winklerian model

杭の水平抵抗, 杭一地盤系の非線形性, 杭の損傷評価, シミュレーション解析, 3D-FEM, 梁ばねモデル

\section{1 はじめに}

近年、発生している海溝型地震や内陸直下型地震では多くの杭基 礎構造物に被害が生じたことが報告されている1,2)。中には、杭基礎 の損傷・破壊が原因となって上部構造が傾斜し、建物の機能性が著 しく損なわれた例も見られた。建築における杭の設計は中地震に対 寸る検証に留められているのが現状 ${ }^{3)}$ であり、大地震に対する耐震 性能を明確にできていない杭基礎が数多く存在する。さらに、近い 将来に高レベル地震動の発生が懸念されており、杭基礎建物が大地 震を被れば、新設、既設を問わず、同様の被害が生じる可能性は高 い。大地震に対する杭基礎の耐震性能を明確にすることは喫緊の課 題と考える。

地震時において、杭基礎には上部構造からの慣性力と同時に地盤 からの強制変位が作用するため、杭の地震時応力の評価には地盤と 建物の動的相互作用を考慮することが必要である。ただし、杭基礎 が用いられるような軟弱地盤では、強震動入力によって地盤は非線 形化し、また杭および上部構造も塑性化するため、地盤と建物の動 的相互作用は複雑となる ${ }^{4)}$ 。そのため、地盤や杭基礎の非線形現象 と構造物の地震時挙動に関する実証データを蓄積することが重要と 考えられる。このような背景の下で、著者らは杭頭の損傷に着目し た杭基礎建物模型の遠心載荷実験 5)を実施し、杭頭と杭周地盤の非 線形化が杭基礎建物の地震応答に影響を及ぼすことを実験的に明ら かにした。ただし、(1)杭周地盤の非線形性として、どのような現象
が地震応答に影響を及ぼしているのかまでは明らかにしていない、 (2)塑性化を伴う杭の耐震性能評価、つまり杭の損傷評価として、杭 応力だけでなく杭のひずみ・変形を考慮しなければならないが6、杭 のひずみ・変形に対して詳細な分析を行っていない、という課題を 残している。大地震に対する杭の損傷を精度良く評価できる簡便な 手法の確立のためには上記の課題を解決する必要がある。

杭基礎建物の地震時挙動に影響を及ぼす杭周地盤の非線形性とし て、地盤の材料非線形性に加えて杭一地盤間で生じるすべり・剥離 等の局所的非線形性が指摘されている4)。しかし、地盤の局所的非 線形性が構造物の地震時挙動に及ぼす影響について検討している研 究例 7,8$)$ は多くない。また、非線形3D-FEM は大地震時に生じる地盤 の局所的非線形性を考慮する手法として有効と考えられ、これまで も模型もしくは実大の振動実験に対するシミュレーション9,10)が実 施されているが、局所的非線形性に焦点を当てたものは少なく、地 盤の局所的非線形性が構造物に及ぼす影響は明確になっていない。 一方、杭頭条件や杭の非線形化が構造物の地震時挙動に及ぼす影響 を分析した実験的研究として、遠心振動実験 ${ }^{11)}$ や大型振動台実験 ${ }^{12)}$ が、解析的研究として、Penzien型多質点モデルを用いた地震応答解

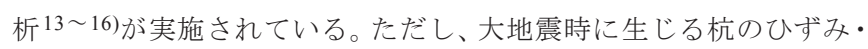
変形を評価する観点に立ち、実験と解析を組み合わせて検証してい る例は少なく、大地震時における杭の損傷評価方法について検討す る余地が残っている。
* 大阪大学大学院工学研究科地球総合工学専攻 助教・博士 (工学)

** 大阪大学大学院工学研究科地球総合工学専攻 教授·博士 (工学)
Assist. Prof., Division of Global Architecture, Graduate School of Eng., Osaka Univ., Dr. Eng. Prof., Division of Global Architecture, Graduate School of Eng., Osaka Univ., Dr. Eng. 
そこで本論文では、杭頭の塑性化に着目した遠心載荷実験のシ ミュレーション解析に基づいてパラメトリックスタディを実施し、 杭頭の損傷評価において適切な解析モデルと考慮すべき影響因子を 明らかにする。具体的には、まず第 2 章で、前報 5)の遠心載荷実験 の結果をシミュレーションできる非線形 3D-FEM モデルを構築し、 杭一地盤系の局所的非線形現象が杭基礎建物の地震応答に及ぼ寸影 響を明らかにする。次に第 3 章で、3D-FEM 解析よりも簡易で、設 計でも用いられることの多い梁ばねモデルによる解析と3D-FEM解 析を比較し、梁ばねモデルの適用性を検証する。最後に第 $4 、 5$ 章で、 杭に作用する上部構造慣性力と地盤変位の両者が杭の損傷評価に及 ぼす影響について、梁ばねモデルを用いた地震応答解析および静的 解析によるパラメトリックスタディを通じて分析し、杭頭の損傷評 価に考慮すべき因子を明らかにする。

\section{3D-FEMによる実験のシミュレーション解析}

本章では、杭頭の塑性化に着目した杭基礎模型の遠心載荷実験に 対して、非線形3D-FEMによる地震応答解析を実施し、解析の有効 性を検証した後に、杭一地盤間に生じる局所的非線形現象が杭基礎 建物の地震応答に及ぼす影響について分析する。

\section{1 乾燥砂地盤における杭基礎建物模型の遠心載荷実験 5)}

実験は、京都大学防災研究所の遠心力載荷装置を用いて $40 \mathrm{~g}$ 場で 行った。図 1 に試験体の概要を示寸。せん断土槽は土槽幅 $45 \mathrm{~cm}$ (加 震方向)、奥行き $15 \mathrm{~cm}$ 、高さ $20 \mathrm{~cm}$ である。図 1 では、土槽・試験体 の寸法を実大スケールで示している。地盤材料は豊浦砂を使用し、 地盤の製作方法は空中落下法を用いた。地盤構成は、せん断土槽の 底から $2 \mathrm{~cm}$ の層を相対密度 $\mathrm{Dr}=90 \%$ で製作し、それより上部の地盤 はややゆるい地盤として $\mathrm{Dr}=60 \%$ で製作した。杭基礎模型は、真鍮 製の基礎構造・板バネ・上部構造で構成されている。基礎の質量は $0.46 \mathrm{~kg}$ (実物大の重量約 $29.5 \mathrm{t}$ 、以下同様)、上部構造の質量は $2 \mathrm{~kg}$ (約 $128 \mathrm{t}$ ）で基礎固定時の固有振動数は約 $105 \mathrm{~Hz}$ （実物大の固有振動数 約 $2.6 \mathrm{~Hz}$ ）である。入力する地震波は、八戸波（八戸 $1968 \mathrm{NS）で}$ ある。図 2 に振動台で計測された入力地震動の加速度時刻歴を、図 3 に加速度応答スペクトル $(h=0.05)$ を示す。実験では、小加震（実 物大の最大加速度 $: 0.35 \mathrm{~m} / \mathrm{s}^{2}$ 、以下同様)、中加震 $\left(1.18 \mathrm{~m} / \mathrm{s}^{2}\right)$ 大加震 $\left(3.17 \mathrm{~m} / \mathrm{s}^{2}\right)$ の順序で加震を行う。なお、大加震は安全限界性能検証 レベルの告示波とほぼ同じ加速度レベルである。

本実験では、図1(b)に示すように、杭頭を早期に塑性化させるた めに、杭頭部を切欠いた杭を用いている。杭地中部の断面は径 $8 \mathrm{~mm}$ 、厚さ $1 \mathrm{~mm}$ (実物大寸法 : 径 $320 \mathrm{~mm}$ 、厚さ $40 \mathrm{~mm}$ 、以下同様)、 基礎下端から土台上端までの長さが $176 \mathrm{~mm}(6640 \mathrm{~mm}$ ）のアルミ管 で、杭頭の切欠き部分の長さは $10 \mathrm{~mm}(400 \mathrm{~mm})$ 、断面は径 $5.34 \mathrm{~mm}$ 、 厚さ $0.67 \mathrm{~mm}$ （径 214 、厚さ $27 \mathrm{~mm}$ ）である。杭の単調載荷曲げ試験 における杭頭部・杭地中部の曲げモーメントー曲率関係を図 4 に示 す。図 4 には、参考のとして $\phi 318.5 \times 9$ の鋼管杭の曲げモーメント 一曲率関係を示している。基礎部は 4 本の杭で支持されており、杭 端は真鍮製の台座に、杭頭は基礎部に固定する。基礎底面と地盤は $3 \mathrm{~mm}(120 \mathrm{~mm})$ 離れている。計測として、地盤にはせん断土槽の底 部と地表面に、水平方向加速度計を設置する。杭基礎模型には、基 礎と上部構造に水平方向加速度計を設置する。また、1 本の杭にひ ずみゲージを 10 レベルに貼り付け、他 3 本の杭にはひずみゲージを 3 レベルに貼り付ける。

\subsection{D-FEM モデル}

2.1 節で示した試験体を 3 次元有限要素でモデル化し、汎用ソフト LS - DYNA ${ }^{17) を}$ 用いてシミュレーションを行う。LS-DYNA は陽解 法に特化したプログラムであり、動的接触問題に対して有効な 3 次 元有限要素解析ツールである。以下では諸元および結果について、 実寸大のスケールで示す。

図 5 に解析モデルを示す。また、表 1 に解析で用いた杭の諸元を、 表 2 に地盤の諸元を、図 6 に地盤のせん断波速度分布を示す。解析 モデルは対称条件を考慮した $1 / 2$ モデルとし、上部構造、地盤の大 きさは模型実験の実寸大の大きさと同じとする。上部構造および基 礎はソリッド要素で剛体として、柱(板ばね)はビーム要素で弾性体 としてモデル化する。上部構造の大きさ、上部質量と基礎の密度は 実験と同じとする。また、解析における上部構造の基礎固定時の固 有周期が実験と同じになるように、柱の曲げ剛性を設定する。地盤 底面の境界条件は固定条件とし、地盤周囲は深さが等しい節点の $\mathrm{x}$ 、 $\mathrm{y} 、 \mathrm{z}$ 方向の変位が同一となるような拘束条件を設定する。また、せ ん断土槽のフレーム質量は無視する。杭一地盤間にはすべり・剥離・

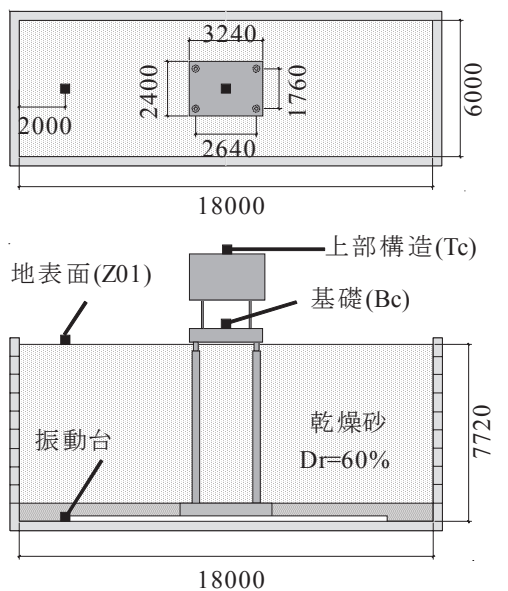

(a) せん断土槽平面 ·立面図

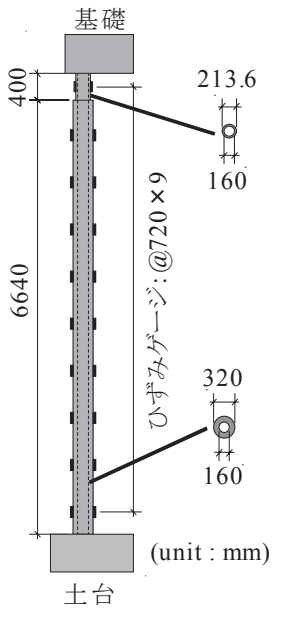

(b) 杭詳細図

図 1 実験装置概要図と杭詳細図（実物大寸法）

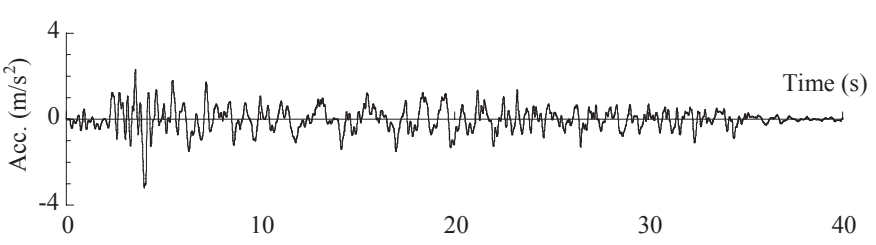

図 2 入力地震動の時刻歴波形（八戸 $1968 \mathrm{NS} \cdot$ 大加震）

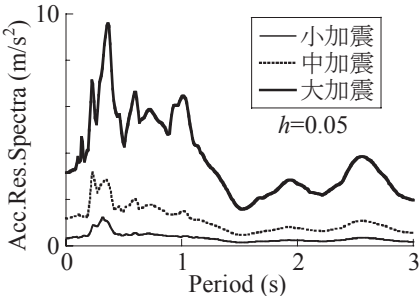

図 3 入力地震動の 加速度応答スペクトル

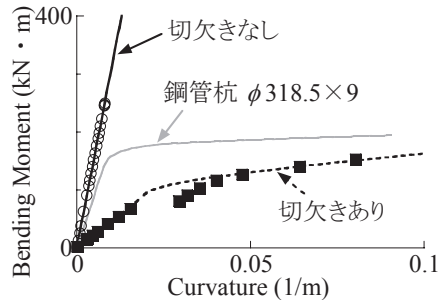

図 4 杭の曲げ特性 
再接触を考慮できる接触条件を設定するために、杭要素と地盤要素 の接触面にコンタクトインターフェイスを設定し、接線方向の摩擦 係数を $\tan \theta(\theta$ は地盤の内部摩擦角）とする。なお、用いた接触条件 は、接触面鉛直反力をぺナルテイ法により算出し、接触面方向の摩擦力 一すべり量関係は剛一完全塑性でモデル化している。杭は解析時間の 短縮を図るためにシェル要素でモデル化し、杭頭部を弾塑性体、杭 頭部以外を弾性体とする。実験で用いた杭の厚さは40mmであり、そ のままシェル要素でモデル化するには厚すぎるため、解析では径 $320 \mathrm{~mm}$ 、厚さ $12 \mathrm{~mm}$ の形状としてモデル化し、解析での曲げ剛性と 降伏モーメントが実験と等価になるように、杭のヤング係数、降伏 応力、降伏後の 2 次剛性を設定する。図 4 に、杭頭部の曲げ試験の 結果に併せて、解析モデルの曲げモーメントー曲率関係を示してい る。解析モデルは実験結果によく対応しており、モデル化は妥当と 考えられる。杭頭と基礎の接合部は、接続する節点を共有させる。

地盤はソリッド要素で弾塑性体としてモデル化する。文献5)では 地盤の非線形特性としてMohr-Coulomb 条件を適用した。ここで、 Mohr-Coulomb条件を用いた弾完全塑性体として地盤をモデル化した
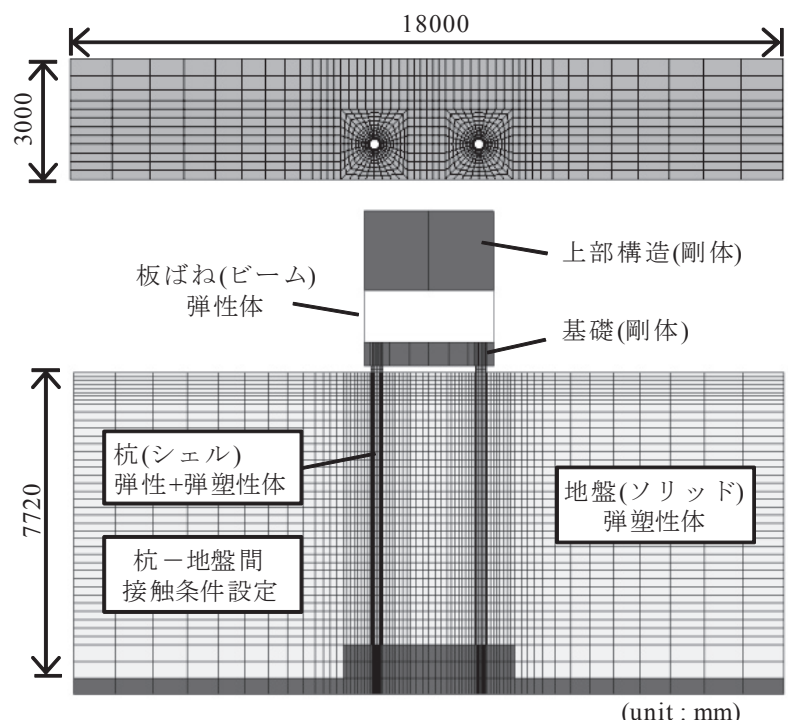

図 5 3D-FEM解析モデル（1/2 モデル）

表 1 杭の諸元

\begin{tabular}{|c|c|c|c|c|c|}
\hline \multicolumn{2}{|c|}{} & 径・厚さ & $E_{p}$ & $E_{p} I_{p}$ & $\sigma_{y}$ \\
\cline { 3 - 6 } \multicolumn{2}{|c|}{} & $\mathrm{mm}$ & $\mathrm{N} / \mathrm{mm}^{2}$ & $\mathrm{kNm}^{2}$ & $\mathrm{~N} / \mathrm{mm}^{2}$ \\
\hline \multirow{2}{*}{ 実験 } & 杭頭部 & $320 \cdot 40$ & \multirow{2}{*}{$7.00 \mathrm{E}+04$} & 4900 & $1.37 \mathrm{E}+02$ \\
\cline { 2 - 5 } \cline { 5 - 6 } & 地中部 & 214.27 & & 33800 & - \\
\hline \multirow{2}{*}{ 解析 } & 杭頭部 & \multirow{2}{*}{320.12} & $3.33 \mathrm{E}+04$ & 4900 & $1.04 \mathrm{E}+02$ \\
\cline { 2 - 5 } & 地中部 & & $2.29 \mathrm{E}+05$ & 33800 & - \\
\hline
\end{tabular}

表 2 地盤の諸元

\begin{tabular}{|c|c|c|c|c|c|c|c|c|c|}
\hline 地層 & 深さ & 層厚 & $v$ & $\rho$ & $V s$ & $G$ & $K$ & $\varphi$ & $h_{\max }$ \\
\hline & $\mathrm{m}$ & $\mathrm{m}$ & & $\mathrm{t} / \mathrm{m}^{3}$ & $\mathrm{~m} / \mathrm{s}$ & $\mathrm{N} / \mathrm{mm}^{2}$ & & $\circ$ & \\
\hline $1 \sim 2$ & $\sim 0.4$ & 0.2 & \multirow{4}{*}{0.33} & \multirow{3}{*}{1.5} & \multirow{3}{*}{ 式(10) } & \multirow{3}{*}{ 式(10) } & \multirow{4}{*}{0.5} & \multirow{3}{*}{32} & \multirow{3}{*}{0.4} \\
\hline $3 \sim 14$ & $\sim 5.2$ & 0.4 & & & & & & & \\
\hline $15 \sim 18$ & $\sim 6.88$ & 0.42 & & & & & & & \\
\hline $19 \sim 20$ & $\sim 7.72$ & 0.42 & & 1.6 & 250 & 100 & & - & - \\
\hline
\end{tabular}

表 3 ヒステリシス土質モデルの諸元

\begin{tabular}{|c|c|c|c|c|c|c|c|c|c|}
\hline 地層 & 深さ & $c$ & $\alpha$ & $\kappa$ & $p_{\text {ref }}$ & $D_{A}$ & $D_{B}$ & $D_{C}$ & $D_{D}$ \\
\hline & $\mathrm{m}$ & $\mathrm{N} / \mathrm{mm}^{2}$ & & & $\mathrm{kPa}$ & & & & \\
\hline $1 \sim 18$ & $\sim 6.88$ & 0.001 & 0.2 & 0.8 & 32 & 0.5 & 1.6 & -8 & -30 \\
\hline
\end{tabular}

場合、地盤が降伏するまでは解析条件として与えた初期剛性を持つ 弾性体として挙動する。一方、文献 18)で指摘されているように、地 盤は小さなひずみ領域から非線形性が現れるため、Mohr-Coulomb条 件を用いた地盤モデルにとって、せん断波速度より算出されるせん 断剛性は初期剛性としてかなり大きめの評価となり、実状に合わせ るためにはせん断剛性を適切に低下させる必要がある。さらに、地 盤が弾性体として挙動する領域においては履歴減衰を考慮できない ため、地盤に履歴減衰の代わりとなる減衰を付与する必要も生じる。 しかし、これらの剛性低下率や付与寸る減衰定数を決定することは 容易ではない。そこで、本解析では地盤の材料非線形モデルとして、 せん断応力ーひずみ関係の履歴減衰を小ひずみ領域から連続的に考 慮できるヒステリシス土質モデル17)を適用する。図7 にヒステリシ ス土質モデルにおける骨格曲線としてせん断応力一せん断ひずみ関 係の一例を示す。また、表 3 に本解析でヒステリシス土質モデルに 入力する諸元を示す。ヒステリシス土質モデルは最大 10 枚まで重敞 られた弾完全塑性材料の積層をもつ入れ子構造の面モデルである。 つまり図 7 に示すように、ヒステリシス土質モデルのせん断応力ー ひずみ関係の骨格曲線は基準圧力下でのポリリニア曲線として定義 され、ポリリニア曲線を構成する直線と同数の弾完全塑性モデルを 重初合わせてモデル化される。ポリリニア曲線を構成する弾完全塑 性モデルには Drucker-Pragerの降伏条件に基づいて圧力依存性が考 慮される。本解析では、せん断応力ーひずみ関係の骨格曲線にROモ デルを適用し、初期せん断剛性はせん断波速度より、降伏せん断応 力は基準圧力下でMohr-Coulombの降伏条件より算出する。また、基 準ひずみ時のせん断応力は降伏せん断応力の 0.5 倍とする。なお、基 準ひずみは降伏せん断応力を初期剛性で除した值である。ROモデル の履歴法則は Masing 則に従うものとし、履歴減衰の最大值は文献 19 )を参照し、大きめの 0.4 とする。本解析モデルに用いられる Drucker-Pragerの降伏条件は次式で表現される。

$$
-\alpha I_{1}+\sqrt{J_{2}{ }^{\prime}}-\kappa=0
$$

ここで、 $\alpha 、 \kappa は$ Drucker-Pragerの降伏条件のパラメータ、 $I_{1}$ は応 力の第 1 不変量、 $J_{2}{ }^{\prime}$ は偏差応力の第 2 不変量である。 $\alpha 、 \kappa$ は 3 軸 圧縮試験での応力状態を仮定して、Mohr-Coulombの降伏条件による 内部摩擦角 $\theta$ およ゙粘着力 $c$ との関係式（次式 ${ }^{20)}$ ) を用いて算出す る。

$$
\alpha=\frac{2 \sin \theta}{\sqrt{3}(3-\sin \theta)}, \quad \kappa=\frac{6 c \cos \theta}{\sqrt{3}(3-\sin \theta)}
$$

式(1)、(2)より、静水圧と内部摩擦角が一定の条件下においては、

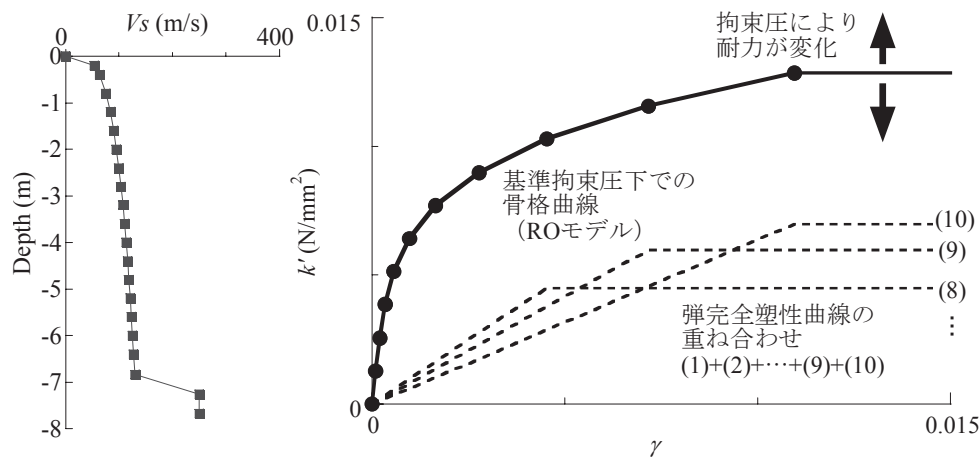

図 6 せん断波速度分布 
降伏条件は $J_{2}^{\prime}$ に支配され、次式で表現できる。

$$
\sqrt{J_{2}{ }^{\prime}}=\alpha I_{1}+\kappa=\left[\frac{1}{6}\left\{\left(\sigma_{1}-\sigma_{2}\right)^{2}+\left(\sigma_{2}-\sigma_{3}\right)^{2}+\left(\sigma_{3}-\sigma_{1}\right)^{2}\right\}\right]^{1 / 2}
$$

ここで、 $\sigma_{1} 、 \sigma_{2} 、 \sigma_{3}$ はそれぞれ最大主応力、中間主応力、最小主 応力である。砂地盤 (粘着力 $c=0)$ において、純せん断状態 $\left(\sigma_{1}=p+k\right.$ 、 $\sigma_{2}=p 、 \sigma_{3}=p-k 、 p$ : 平均垂直応力）で Drucker-Pragerの降伏条件を満 たすせん断応力 $k$ ' は次式で表わされる。

$$
k^{\prime}=\sqrt{J_{2}{ }^{\prime}}=3 \alpha p
$$

一方、同一条件下で Mohr-Coulomb の降伏条件を満たすせん断応 力 $k$ （以降、降伏せん断応力）は次式を満たす。

$$
2 k=\sigma_{1}-\sigma_{3}=\left(\sigma_{1}+\sigma_{3}\right) \sin \theta=p \sin \theta
$$

式(1)〜(5)より、次式が成り立つ。

$$
k^{\prime}=\frac{2}{\sqrt{3}} k
$$

式(6)の意味しているところは、Drucker-Pragerの降伏条件を用い るヒステリシス土質モデルに対して Mohr-Coulomb 条件に基づく降 伏せん断応力を入力すると、その地盤のせん断応力は入力した降伏 せん断応力の $2 / \sqrt{3}$ 倍にまで達するということである。そこで、ヒス テリシス土質モデルに対しては、降伏せん断応力にあらかじめ $\sqrt{3} / 2$ 倍した值を入力する。ヒステリシス土質モデルのダイレイタンシー 特性は $\mathrm{z}$ 方向のみ考慮され、文献 21) と同じ理論を用いて表現され る。すなわち、地盤要素の体積ひずみ $\varepsilon_{\mathrm{v}}$ は、図 8 に示すようにせん 断変形を受けることにより土粒子どうしが乗り上がり膨張する成分 $\varepsilon_{\mathrm{r}}$ と、構造的に弱い部分が崩れて収縮する成分 $\varepsilon_{\mathrm{g}}$ の重㸚合わせで表 現され、 $\varepsilon_{\mathrm{r}}$ と $\varepsilon_{\mathrm{g}}$ は合せん断ひずみ $\Gamma$ と累加せん断ひずみ $G^{*}$ を用いて、

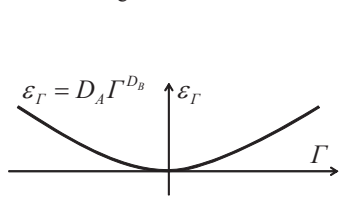

(a) 膨張成分

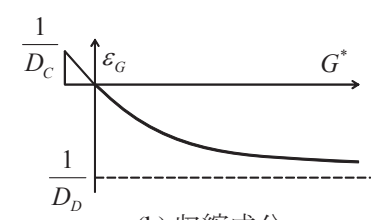

(b) 収縮成分
図 8 ダイレイタンシーを構成するひずみ成分

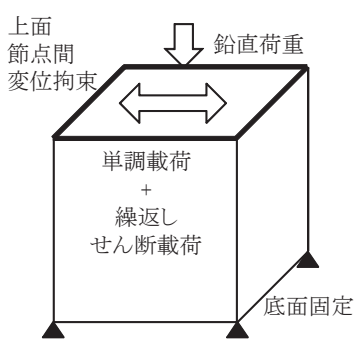

図 9 有限要素載荷試験の概要

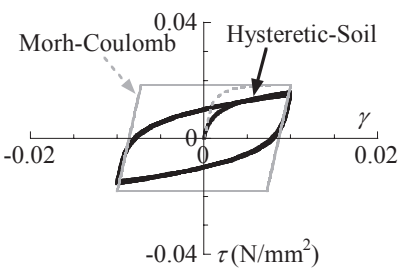

(a) せん断応力ーひずみ関係

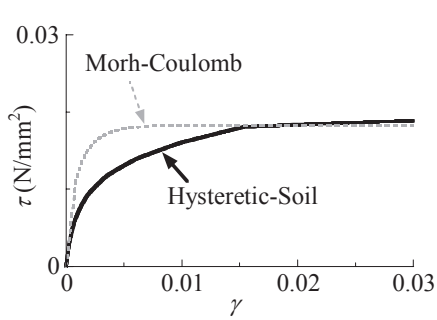

図 10 単調載荷試験結果

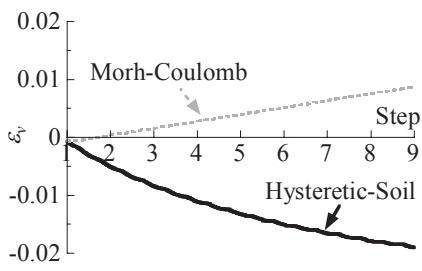

(b) 載荷による体積ひずみ
図 11 繰返し載荷試験結果
次式で評価される。

$$
\begin{aligned}
& \varepsilon_{v}=\varepsilon_{r}+\varepsilon_{g} 、 \quad \varepsilon_{r}=D_{A} \Gamma^{D_{B}} 、 \quad \varepsilon_{g}=\frac{G^{*}}{D_{C}+D_{D} G^{*}} \\
& \Gamma=\left(\gamma_{x z}{ }^{2}+\gamma_{y z}{ }^{2}\right)^{0.5} \\
& G^{*}=\int\left(d \gamma_{x z}{ }^{2}+d \gamma_{y z}{ }^{2}\right)^{0.5}
\end{aligned}
$$

本解析では、ダイレイタンシー特性に入力する係数 $D_{A} 、 D_{B} 、 D_{C}$ $D_{D}$ として文献 21)を参照し、表 3 の通り入力する。ヒステリシス土 質モデルの履歴則には Masing 則が用いられている。

地盤の内部摩擦角は、杭基礎建物の地震応答によって杭周地盤に 生じるひずみが局所的にかなり大きくなることを考慮して、文献22) より豊浦砂の極限状態における内部摩擦角 $32^{\circ}$ を適用する。地盤の 初期せん断剛性 $G$ は、各層のせん断波速度 $V_{s}$ を用いて式(10)で設定 する。

$$
G=\rho \cdot V s^{2} 、 \quad V s=\alpha(H)^{1 / 4}
$$

ここで、 $\rho$ は地盤の密度、 $H$ は深さである。係数 $\alpha$ は重複反射理論 による一次元波動論（Shake）を用いて、小加震時の加速度応答波形 が実験結果と対応するように算出する。このシミュレーションでは $\alpha=76$ が概放適当と判断した。設定したせん断波速度分布は図 6 の通 りである。なお、本論文で同定した豊浦砂のせん断波速度は、式10) を用いて豊浦砂による模型地盤のせん断波速度を同定している文献 23)〜 25)に比べると小さくなっている（文献 25)では $\alpha=140$ 程度)。 この理由として、模型地盤の設置方法や実験装置の違い等が考えら れるが、明確な理由は分かっていない。模型地盤の振動実験に対し てシミュレーション解析を実施する際には、実験ごとに小地震に対 するせん断波速度を同定してモデル化する必要があると考えられる。 相対密度 $\mathrm{Dr}=90 \%$ の層は、せん断波速度を $250 \mathrm{~m} / \mathrm{s}$ とする。

Mohr-Coulomb モデルとヒステリシス土質モデルを比較するため に、図 9 に示寸有限要素を用いた載荷試験をそれぞれのモデルで実 施した。1メッシュ立方体モデルで底面を固定し、上面に鉛直荷重 を作用させながら水平方向の強制変位を与える。強制変位は 1 方向 に作用させる単調載荷と最大せん断ひずみ $1 \%$ の正負交番繰返し載 荷とする。検討では、実験モデルの深さ $2.2 \mathrm{~m}$ に相当する $32.3 \mathrm{kN} / \mathrm{m}^{2}$ の鉛直荷重を作用させる。図10に単調載荷におけるせん断応力一ひ ずみ関係を示す。地盤が完全に降伏するまでの領域で、ヒステリシ ス土質モデルの割線剛性はMohr-Coulomb モデルに比べて小さい。 また、ヒステリシス土質モデルにおいて、地盤が完全に塑性化する 時のせん断応力はMohr-Coulomb モデルとほぼ等しい。図 11 に繰返 しせん断載荷におけるせん断応力ーひずみ関係と載荷による体積ひ

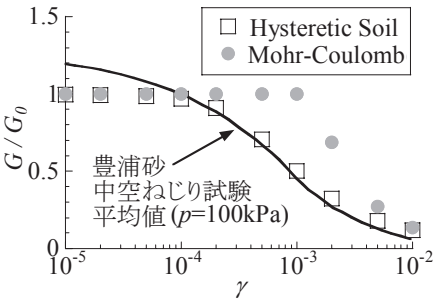

(a) せん断剛性低下率

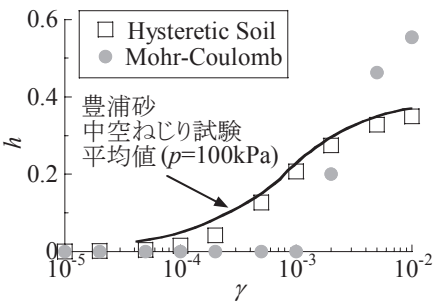

(b) 等価粘性減衰定数
図 12 既往の試験 ${ }^{19)}$ と本解析における繰返し変形特性の比較 
ずみの変化を示す。なお、図11(b)では1ステップ当たり 1 回の繰返 し載荷を表す。図11(a)より、Mohr-Coulombモデルは平行四辺形の 履歴を描いている一方で、ヒステリシス土質モデルは紡鍾形の履歴 を描いている。また図11(b)より、繰返し載荷に伴ってMohr-Coulomb モデルは体積が増加しているのに対して、ヒステリシス土質モデル は体積が減少している。図12 に本解析における地盤モデルの繰返し 変形特性を既往の試験19) と比較した結果を示す。図中の曲線は文献 19)で行われた豊浦砂の中空ねじりせん断試験の平均值 (平均拘束圧 $p=100 \mathrm{kPa}$ ）を表している。図12より、ヒステリシス土質モデルによ る解析結果は Mohr-Coulomb モデルに比べて、中空衫じりせん断試 験結果を良好にシミュレーションできている。

\section{3 実験結果と解析結果の比較}

解析結果として、図 13 に(a)小加震、(b)大加震の上部質量および 地表面の加速度時刻歴波形を示す。いずれの加震においても、解析 結果は実験結果を精度よくシミュレーションできている。図14に図 13 の加速度時刻歴波形について、地表面応答に対する上部質量応答 のフーリエスペクトル比を示す。それぞれのフーリエスペクトルに は、バンド幅 $0.2 \mathrm{~Hz}$ の Lag ウィンドウにより平滑化を行っている。い ずれの加震においても、地表面応答に対する上部質量応答のフーリ エスペクトル比は実験と解析で良好に対応している。なお、地盤底 面に対する地表面応答のフーリエスペクトル比より判断すると、自
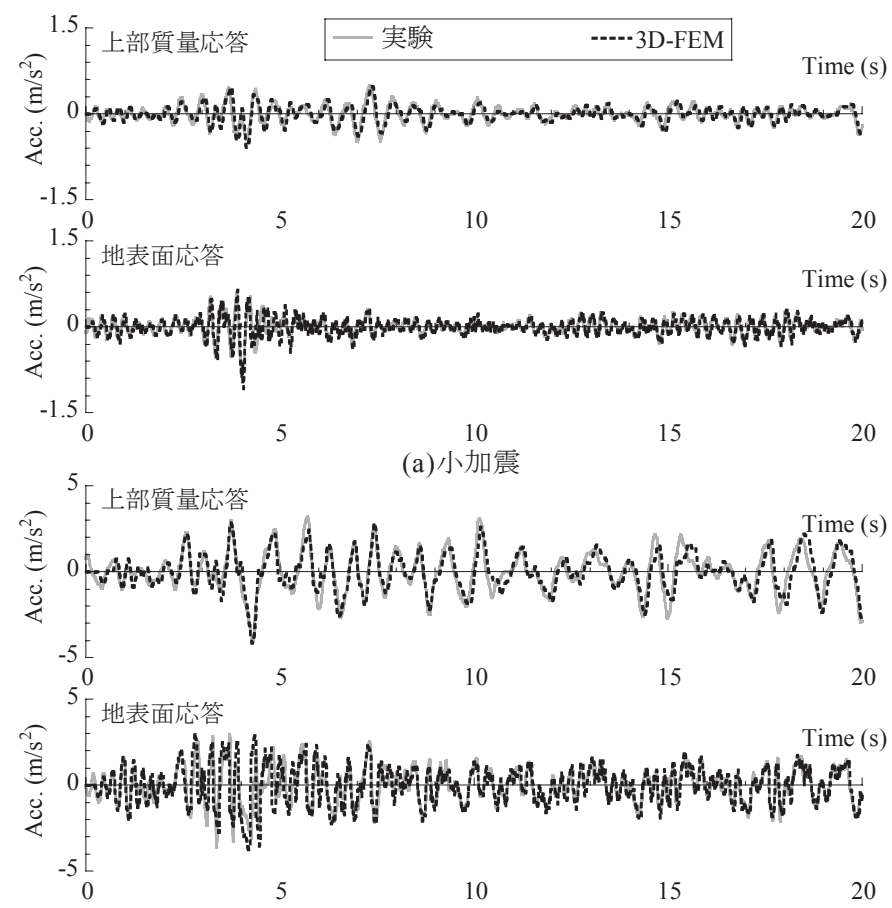

(b)大加震

図 13 加速度時刻歴波形

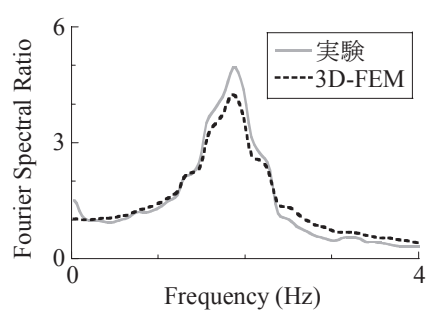

(a)小加震

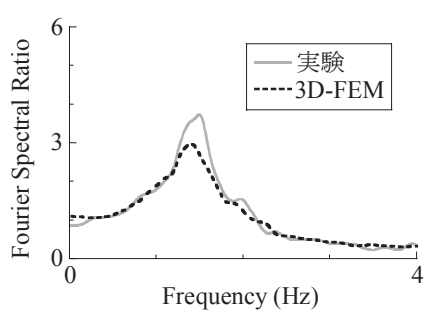

(b)大加震
図 14 地表に対する上部質量のフーリエスペクトル比
由地盤の固有振動数は小加震で $4.07 \mathrm{~Hz}$ 、大加震で $3.83 \mathrm{~Hz}$ 、図 14 上 り判断すると、連成系の固有振動数は小加震で $1.86 \mathrm{~Hz}$ 、大加震で $1.39 \mathrm{~Hz}$ となっており、地盤と杭の相互作用効果により連成系の固有 振動数が上部構造の固有振動数 $2.6 \mathrm{~Hz}$ よりも小さくなっていること、 自由地盤に比べて連成系の固有振動数が小さいことが分かる。図 15 に杭の最大曲率分布を示す。3D-FEMの結果として、載荷方向に並 ぶ2本の杭を示す。実験では載荷方向の1本のみ計測しているが、い ずれの加震においても、解析結果の $\mathrm{P} 2$ は実験結果をシミュレーショ ンできている。以上より、せん断応力ーひずみ関係の履歴減衰を小 ひず夕領域から連続的に考慮できる材料特性と杭一地盤間の接触条 件を用いた非線形 3D-FEMにより、乾燥砂地盤における杭基礎建物 の遠心振動実験を精度良くシミュレーションできる。

\section{4 杭一地盤間のすべり・剥離が地震時挙動に及ぼす影響}

大地震時に生じると考えられる杭一地盤系の局所的非線形性とし て、杭周地盤の材料非線形に加えて杭一地盤間のすべり・剥離が挙 げられる。本節では杭一地盤間のすべり・剥離が杭基礎の地震応答 に及ぼす影響を分析する。

図16にシミュレーション解析で杭一地盤間のすべり・剥離条件を パラメータとした動的解析の結果として(a)地表に対する上部質量の フーリエスペクトル比、(b)杭の最大曲率分布を示寸。図中の「基本 モデル」は杭一地盤間に接触条件を考えた 2.3 節での結果、「固着」 は「基本モデル」の杭一地盤間に接触条件を与えずにすべり・剥離 を許さない条件とした場合の結果、「摩擦なし」は「基本モデル」の 杭一地盤間の摩擦係数を 0 としてすべりを卓越させた場合の結果で ある。図16(a)よりフーリエスペクトル比においては、すべり・剥離 が生じない「固着」に比べて、す心゙り・剥離が生じる「基本モデル」 及び「摩擦なし」のピーク振動数は低振動数にシフトし、検討ケー スにおいては1 割程度変化している。また、図16(b)より杭の曲率に おいては、杭頭曲率および地中部最大曲率に接触条件の影響が見ら れ、すべりが最も卓越する「摩擦なし」の曲率は他のケースに比べ て 1 割程度大きい。
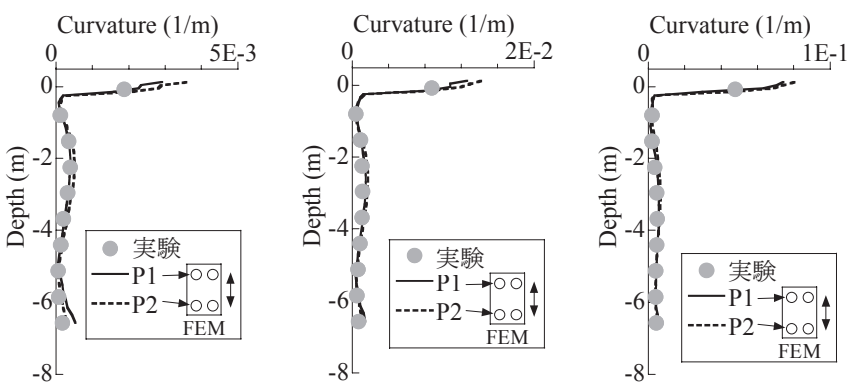

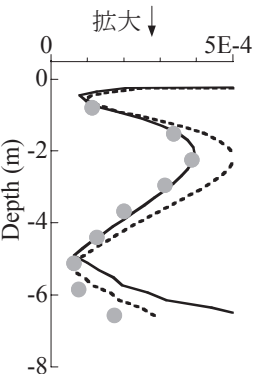

(a)小加震

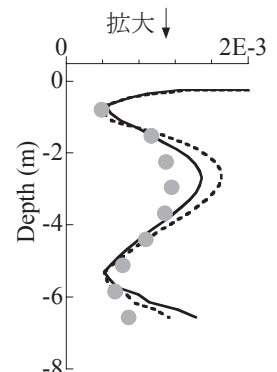

(b) 中加震

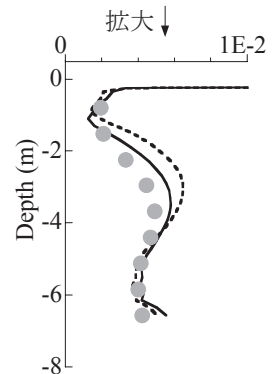

(c)大加震
図 15 杭の最大曲率分布 
次に、杭一地盤間のすべり・剥離が杭周地盤ばねに及ぼす影響を 検討するために、シミュレーション解析のモデルと同じモデルを用 いて、基礎に対して静的 1 方向に強制変位（単調載荷・漸増振幅繰 返し載荷）を与える解析を実施する。まず図 17 に、杭頭単調載荷解 析より得られた地盤反力ー変位関係（GL-0.8m の位置）を示す。図 17(a)は地盤の塑性化を許さない条件での解析結果、図 17(b)、(c)は 地盤の塑性化を許す条件での解析結果である。図 17(b)、(c)中には 基本モデルの各加震レベルにおける動的応答の最大変位に対応する 点を骨格曲線上に示している。また、地盤反力は載荷方向に並ぶ 2 本の杭の平均值とし、杭に作用するせん断力の差分で算出している。 まず小加震応答の変位レベルで見ると図17(a)より、地盤の塑性化を

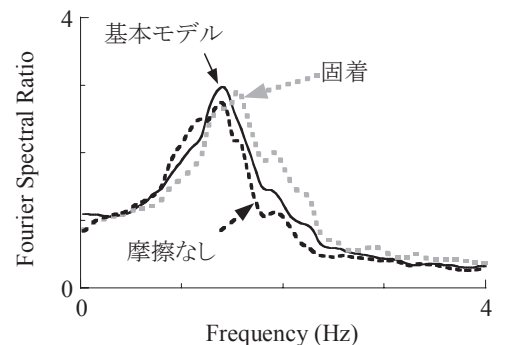

(a) 地表に対する上部質量のフーリエスペクトル比

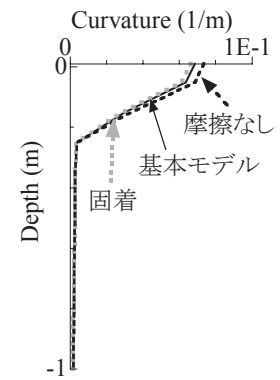

(b-1) 最大曲率分布（杭頭部）

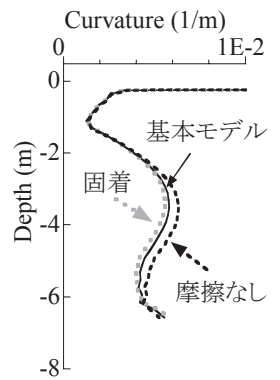

(b-2) 最大曲率分布（地中部）
図 16 杭一地盤間のすべり・剥離条件の影響
許さない条件では、「固着」と「基本モデル」に差が生じており、剥 離の有無の影響が認められる。一方、図17(b)より、地盤の塑性化を 許寸条件では、「固着」と「基本モデル」の差が小さく、地盤が大き く塑性化しない領域で杭一地盤間の剥離の影響が現れることが分か る。「摩擦なし」の剛性は「基本モデル」よりも小さく、杭一地盤間 の寸べりは地盤の材料非線形性の有無によらず地盤反力一変位関係 に影響している。次に地盤の塑性化を許す条件で中加震応答から大 加震応答の変位レベルについて見ると、図17(c)より、変位の増大に 伴って「固着」、基本モデル」の地盤反力の差はいったん大きくなっ た後小さくなる傾向を示す。地盤反力の差がいったん大きくなるの は、基本モデルですべりが発生したことによる。また、差が小さく なるのは、「基本モデル」に与えている摩擦角が地盤の内部摩擦角之 同一であり、杭変位の増大に伴って杭周地盤自体が極限状態に近づ くことにより、両モデルの差が小さくなることに起因すると考えら れる。さらに、「摩擦なし」と他の 2 ケースの差は大きくなる。これ は、これは、「摩擦なし」は他の 2 ケースに比べて、杭一地盤間の摩 擦力による地盤の抵抗を全く期待できないため、初期剛性および極 限地盤反力共に固着や基本モデルに比べて小さくなることが原因と と考えられる。

続いて図 18 に、地盤弾塑性条件下において杭頭漸増振幅繰返し載 荷解析より得られた地盤反力ー変位関係（GL-0.8m の位置）を各加 震レベルに分けて示す。図中には基本モデルの各加震レベルにおけ る動的応答の最大変位に対応する点を履歴曲線上に示している。ま ず図 18(a)より小加震応答の変位レベルにおいては、「固着」、「基本 モデル」、摩擦なし」の順に地盤反力が小さくなる。図17(b) と比心゙ ると図18(a)では「固着」と「基本モデル」の差が大きくなっている。 これは図 17 が単調載荷なのに対して図 18 は漸増振幅繰返し載荷で あり、「固着」は載荷方向を反転させた後、杭周地盤がすぐに杭に抵 抗するのに対して、「基本モデル」では杭の載荷方向後ろ側に生じる

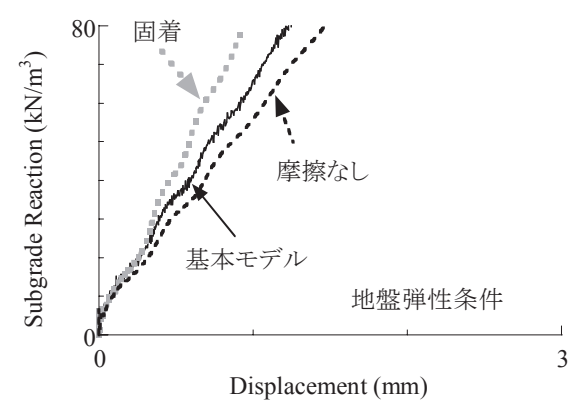

(a) 地盤弾性条件

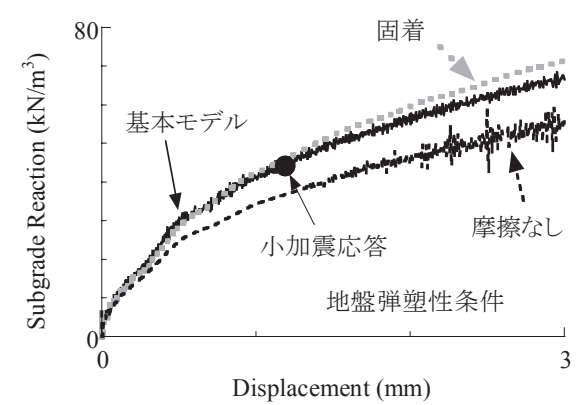

(b) 地盤弾塑性条件・小加震レベル

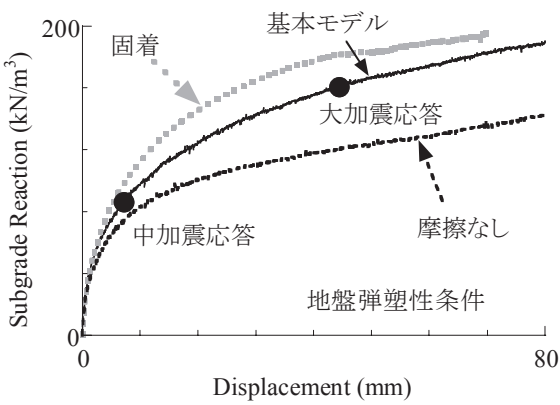

(c) 地盤弾塑性条件・大加震レベル

図 17 単調載荷時の地盤反力一変位関係 (GL.-0.8m)

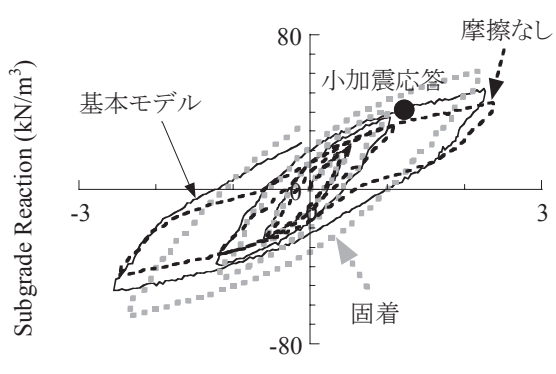

Displacement (m)

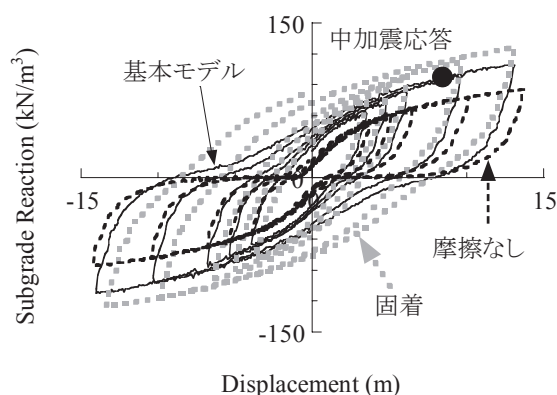

(b) 中加震レベル $(\sim 15 \mathrm{~mm})$

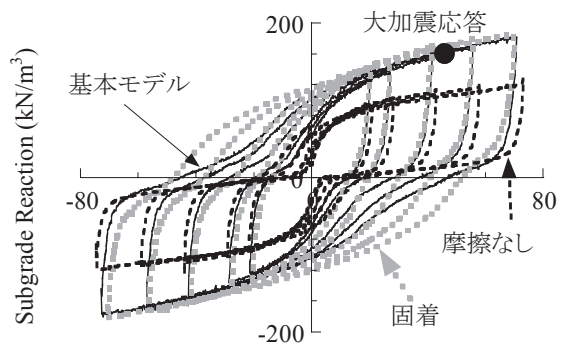

Displacement (m)

図 18 地盤弾塑性条件下での漸増振幅繰返し載荷時の地盤反力－变位関係（GL.-0.8m） 
剥離により、載荷方向を反転させた後、杭周地盤が杭に抵抗するま で「固着」よりも杭変位を要することによる。次に図 18(b)、(c)よ り、中加震応答から大加震応答の変位レベルにおいては杭 - 地盤間 の剥離が影響し、地盤反力一变位関係の履歴特性は逆 $\mathrm{S}$ 字形に近づ くことが分かる。また、単調載荷の場合と同様に、変位の増大に伴っ て「固着」、基本モデル」の地盤反力の差は小さくなり、「摩擦なし」 と他の 2 ケースの差は大きくなる。特に、大加震応答最大変位に対 応する地盤反力を見ると、「摩擦なし」の地盤反力は他 2 ケースに比 べて3割程度小さくなっている。この影響が図16に現れていると考 えられる。ただし、「摩擦なし」と他の 2 ケースで地盤反力 - 変位関 係の差（約 3 割）に比べるとフーリエスペクトル比及び杭の最大曲 率の差（約 1 割）は小さい。以上より、杭一地盤間のすべり・剥離 は上部構造の加速度応答及び杭に生じる最大曲率にある程度の影響 を及ぼすため、解析の精度を高めるためにはこれらを適切に評価す ることは重要と考えられる。

\section{3 多質点系梁ばねモデルと 3D-FEM の比較}

本章では、3D-FEM解析よりも簡易で設計でも用いられることが 多い多質点系梁ばねモデルで遠心載荷実験のシミュレーション解析 を実施し、3D-FEM解析を比較することにより、梁ばねモデルの適 用性を検証する。。なお、本論文では解析プログラムとして、RESP - F3 $\mathrm{T}^{26)}$ を用いる。

\section{1 解析モデル}

図19に遠心載荷実験をモデル化した多質点系地盤一杭一建物連成 梁ばねモデルを示す。上部質量および基礎は集中質点、柱(板ばね) は曲げせん断棒としてモデル化する。杭は曲げせん断棒でモデル化 し、杭の節点には杭周地盤ばねを設置する。杭をモデル化した曲げ せん断棒の剛性および耐力は、図 4 に示した杭模型の曲げ試験の結 果にフィッティングするようにトリリニア型の復元力特性を持つ弾 塑性モデルで設定する。本解析では杭質点の付加質量を無視し、杭 周地盤ばねにはせん断ばねを考慮しない。上部質量、柱、基礎の質 量および上部構造物の基礎固定時の固有振動数は実験と同じとする。 また、本解析は多入力解析とし、杭周地盤ばねには自由地盤応答と して基盤に対する相対変位および速度を入力する。自由地盤応答は 2 章の FEM解析で算出した自由地盤の変位、速度応答を用いる。杭

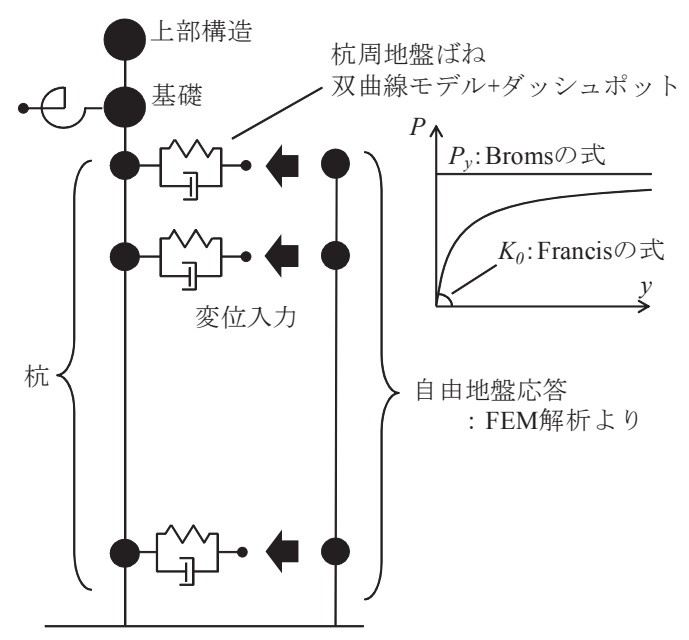

図 19 多質点系地盤一杭一建物連成梁ばねモデル
周地盤ば初の非線形特性は文献 27)等よく用いられている双曲線モ デル +紡錘形の Masing 則とする。杭周地盤ばねの初期剛性 $K_{0}$ には Francis の式27)を用いて次式により決定する。

$$
K_{0}=k_{f s} l^{\prime} 、 \quad k_{f s}=\frac{1.3 E_{s}}{1-v_{s}^{2}}\left(\frac{E_{s} B^{4}}{E_{p} I_{p}}\right)^{1 / 12} N_{P}
$$

ここで、 $E_{s}$ : 地盤の弾性係数（せん断波速度より算出）、 $v_{s}$ : 地盤の ポアソン比、B: 杭径、 $E_{p}$ : 杭のヤング係数、 $I_{p}$ : 杭の断面 2 次モーメ ント、 $N_{p}$ : 杭本数、 $l^{\prime}$ : 杭質点の支配長さである。杭周地盤ばねの耐 力 $P_{y}$ は Broms の極限水平地盤反力28)を用いて次式により決定する。

$$
P_{y}=3 \sigma_{0} K_{p} B l^{\prime} N_{P}
$$

ここで、 $\sigma_{0}$ : 地盤深さに対する上載圧、 $K_{p}:$ 受働土圧係数である。図 20 に梁ばねモデルと 2.4 節で示したFEMモデルの単調載荷解析にお ける杭周地盤ばねを比較して示す。図20(a)より、HD モデルはFEM モデルに比べて変位約 $10 \mathrm{~mm}$ までの割線剛性の変化率が大きく、 FEMモデルに完全にフィッティングさせることは難しい。大加震時 の応答変位である約 $45 \mathrm{~mm}$ を見ると、本検討で設定した杭周地盤ば 水の地盤反力は摩擦なしと基本モデルの間の值となっている（図 20(a))。また、等価粘性隇衰定数は FEMのどのモデルよりも大きめ の評価となっている（図20(b)）。杭周地盤ばねのダッシュポットは Gazetas の式23)を用いて次式により決定する。

$$
c_{g s}=1.57 \rho B\left(V_{L a}+V_{s}\right)
$$

ここで、 $V_{L a}:$ Lysmerの波動速度 $\left(=3.4 V_{s} / \pi\left(1-v_{\mathrm{s}}\right)\right)$ である。ダッ シュポットの算定に用いるせん断波速度は、自由地盤の非線形性を 考慮し、自由地盤の最大応答時の等価せん断剛性より算出した等価 な值とする。

\section{2 解析結果}

図 21 に梁ばねモデルによる地震応答解析結果を実験結果及び FEM 解析結果と比較して示寸。図21(a)、(b)の上部質量応答、(c)の 杭の最大曲率分布、(d)の地盤の最大変位分布、(e)の地盤反力一变 位関係のいずれについても、梁ばねモデルによる解析は実験および FEM 解析と概社対応している。2.4 節で示したように、杭一地盤間 の接触条件によって、上部構造の加速度応答、および杭の曲率は影 響を受けるが、その影響度は大きくない。よって、簡易な多質点系 梁ばねモデルを用いた多入力解析によっても、実験を概ねシミュ レーションできると考えられる。

\section{4 杭頭の塑性化が上部構造慣性カに及ぼす影響}

本章では杭頭の剛性及び耐力をパラメータとしたパラメトリック

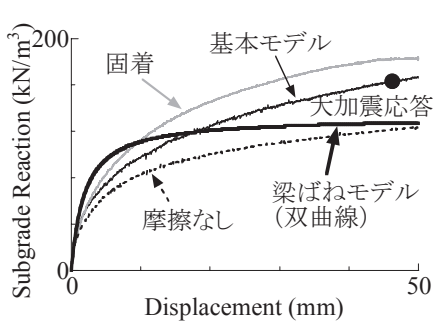

(a) 地盤反力－変位関係

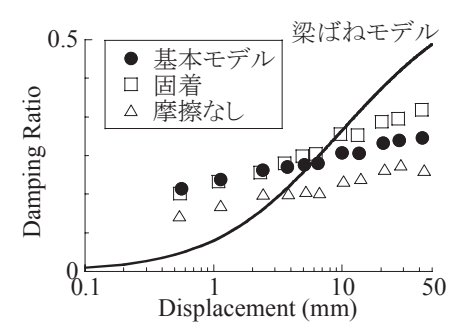

(b) 等価粘性減衰定数
図 20 梁ばねモデルと FEM の杭周地盤ばねの非線形特性 (GL.-0.8m) 
スタディにより、杭の塑性化が上部構造慣性力に及ぼす影響を分析 寸る。図22に解析パラメータとする杭頭の曲げモーメントー曲率関 係を示す。解析では、杭頭弾性条件で実験杭の切欠きなしの曲げ剛 性 $K_{0}$ を規準として、曲げ剛性を $K_{0}$ から $0.04 K_{0}$ まで変化させた。ま た、杭頭弾塑性条件で曲げ剛性 $K_{0}$ 及び切久きありの曲げ剛性 $K_{1}$ を 持った杭で、実験杭の切欠きありの降伏曲げモーメント $M_{y}$ を規準と して、降伏曲げモーメントを $M_{y}$ から $3 M_{y}$ まで 3 レベルに変化させた。 図23に杭頭剛性に対する上部構造慣性力の最大応答值を検討地震動 別に示す。なお、図 23 の横軸は杭頭剛性 $K$ を曲げ剛性 $K_{0}$ で規準化 した $K / K_{0}$ で示している。また、杭頭弾塑性条件の結果については、 杭頭剛性が逐次変化するが、図23では杭頭曲率が最大となる時刻に おける杭頭曲げモーメントー曲率関係の割線剛性を $K_{0}$ で規準化し て、上部構造慣性力の最大応答值をプロットしている。図より、実 験においては杭頭剛性の変化、及び杭頭部の履歴減衰の両方が影響 し、杭頭に作用する上部構造慣性力が変化する。よって、杭頭の損 傷を適切に評価するためには、杭頭の塑性化を反映させた上部構造 慣性力を設定する必要がある。

\section{5 杭頭の損傷評価における地盤変位の影響}

本章では文献6)を参照し、杭の曲率を用いて杭頭の損傷を評価す る中で、杭に作用する外力が杭頭曲率に及ぼす影響を分析する。こ こで検討する杭基礎建物は第 4 章までで分析した上部構造を杭径 $318.5 \mathrm{~mm}$ の実大鋼管杭 4 本で支持したものとする。

まず、第3、4 章と同じ梁ばねモデルを用いて地震応答解析（多入

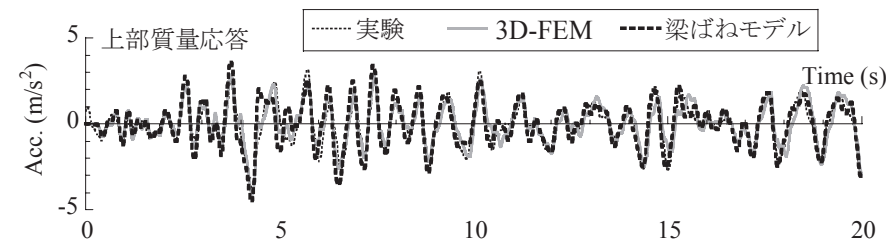

(a) 上部質量の加速度時刻歴波形

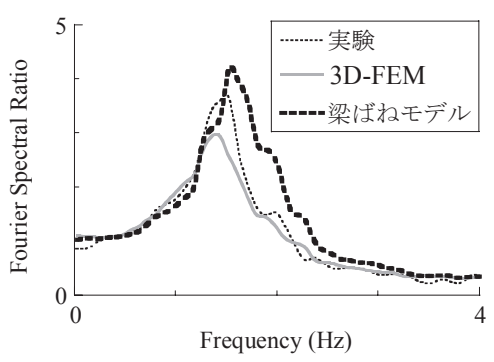

(b) フーリエスペクトル比上 部質量/地表

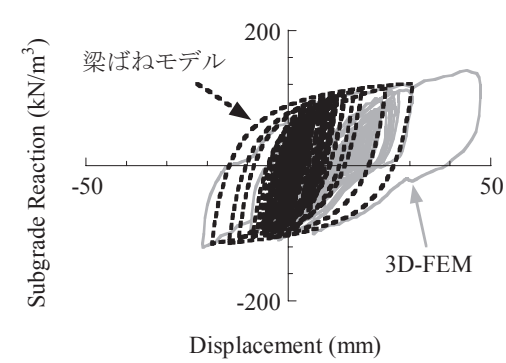

(e) 地盤反力一変位関係 (GL.-0.8m)

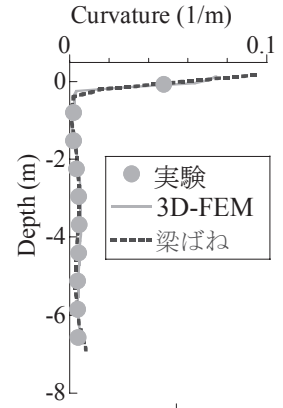

拡大 、

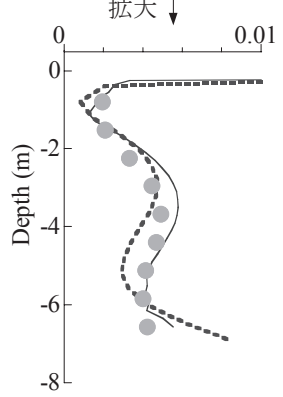

(c) 最大曲率分布
図 21 梁ばねモデルによる大加震のシミュレーション結果
力解析）を実施する。次に、地震応答解析より得られる最大杭頭せ ん断力及び地盤の最大変位分布を外力として静的解析を実施する。 ここで静的解析は図24で示すように、杭の塑性率を(1)杭頭に作用す る慣性力のみで静的解析（図 24(a)、以下、慣性力作用)、(2)杭頭に 作用する慣性力と地盤変位の両方を杭に作用させる応答変位法によ り評価する。応答変位法では外力を作用させる方法として、上部構 造慣性力と地盤変位を同時に作用させ、慣性力と地盤変位が同方向 の場合（図24(b)、以下、同方向作用）と逆方向の場合（図24(c)以 下、逆方向作用）の 2 種類を検討寸る。鋼管杭は厚さの異なる4 ケー スを想定する。図25に静的解析で検討する杭の曲げ特性を示す。同 図より、鋼管杭の厚さが厚くなると、曲げ剛性及び曲げ耐力が増大 する。

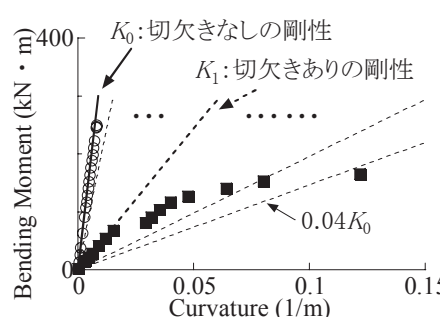

(a) 杭頭弾性条件

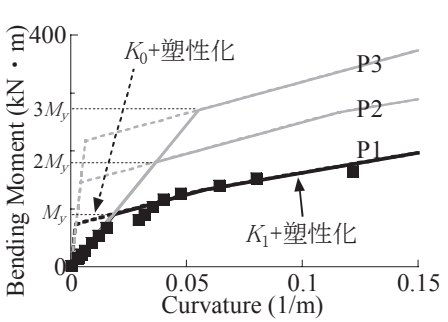

(b) 杭頭弾塑性条件
図 22 解析パラメータとする杭頭の曲げモーメント曲率関係

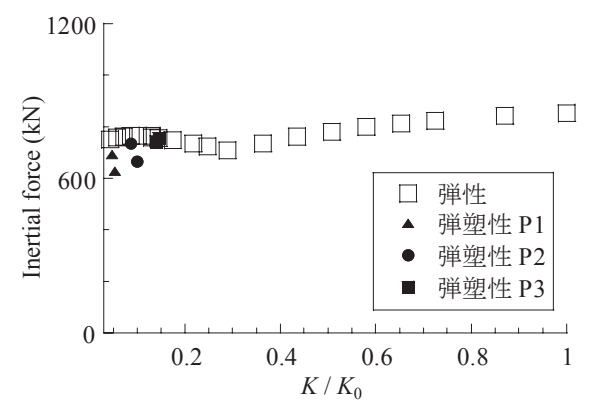

図 23 杭頭剛性に対する上部構造慣性力の最大応答值

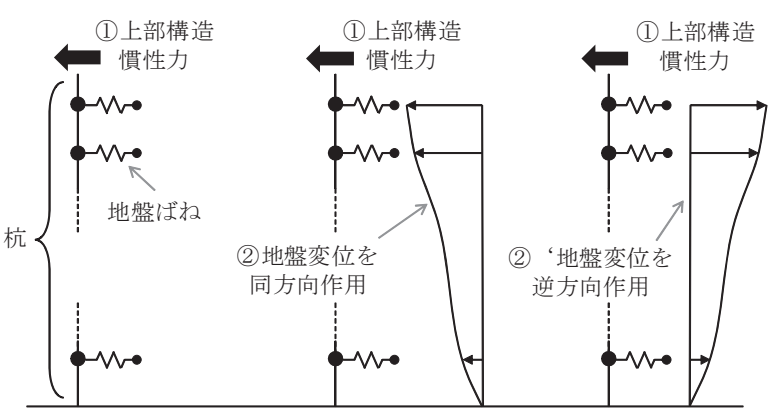

(b) 慣性力 +

(c) 慣性力 +

(a) 慣性力のみ
地盤変位（逆方向）

図 24 検討する静的解析手法

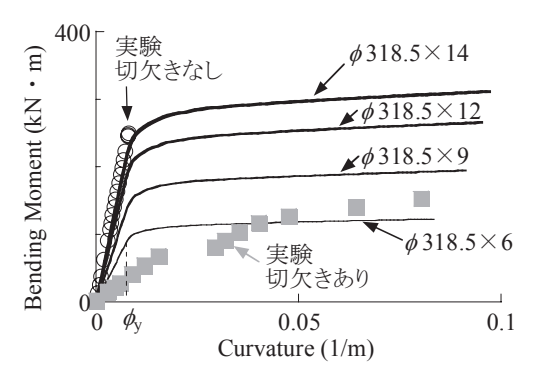

図 25 静的解析で検討する杭の諸元 
本章の検討で用いる地震波は、実験で用いた八戸波（大加震）お よび安全限界性能検証用の告示波（ランダム位相）である。図26に 基盤波（E+F 波）の加速度応答スペクトル $(h=0.05)$ を、図 27 にそ れぞれの基盤波に対する自由地盤の最大変位分布を示す。八戸波の 地盤変位は告示波の 2 倍以上となっている。

図 28 に八戸波での静的解析と動的解析の最大曲率分布（杭頭部 分）を比較して示す。同図では杭の曲率応答を、杭の曲げ特性のう ち第 1 折れ点の曲率 $\phi_{\mathrm{y}}$ で除して規準化した值を示している。まず静 的解析において、杭頭曲率は同方向作用が最も大きくなる。次に、図 28(a)〜(d)のいずれにおいても、同方向作用の杭頭曲率は動的解析 よりも大きくなっている。さらに、動的解析および同方向作用の杭 頭曲率は慣性力作用に比べると大きい。特に、図28(c)では動的解析 および同方向作用の杭頭曲率は慣性力作用の3倍以上となっている。 これは、動的解析において杭頭曲率応答最大時に杭頭慣性力と地盤 変位がほぼ同方向に作用したこと、杭頭慣性力のみでは塑性化しな かった杭頭が地盤変位を考慮することによって塑性化し、大きな曲

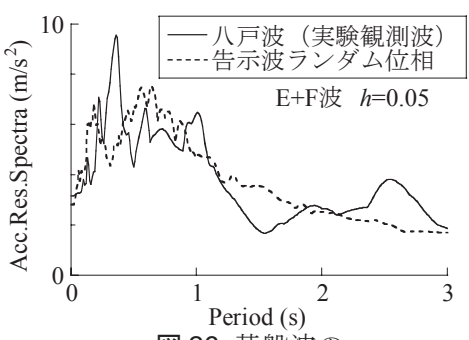

図 26 基盤波の 加速度応答スペクトル

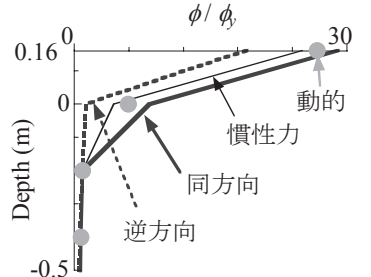

(a) $\phi 318.5 \times 6$

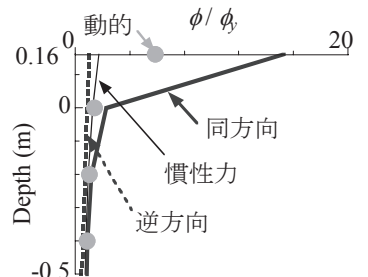

(c) $\phi 318.5 \times 12$

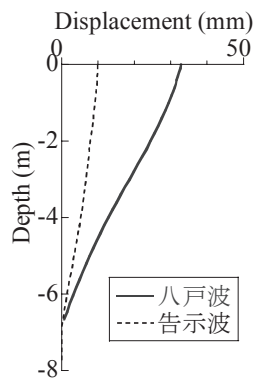

図 27 地盤の最大変位分布

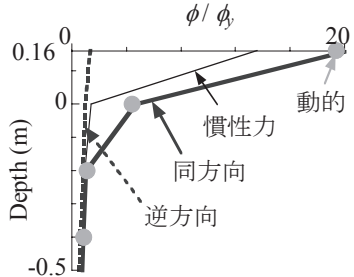

(b) $\phi 318.5 \times 9$

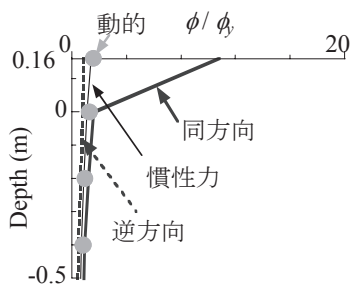

(d) $\phi 318.5 \times 14$
図 28 八戸波での静的 ・ 動的解析の杭曲率の比較

表 4 慣性力作用に対する

動的解析・同方向作用の杭頭曲率の比率

\begin{tabular}{|c|c|c|c|c|c|}
\hline \multirow{2}{*}{$\begin{array}{c}\text { 杭頭 } \\
\text { 曲率 }\end{array}$} & \multirow{2}{*}{ 板厚 } & \multicolumn{2}{|c|}{ 八戸波 } & \multicolumn{2}{c|}{ 告示波 } \\
\cline { 3 - 6 } 動的 & & 杭頭弾性 & 杭頭弾塑性 & 杭頭弾性 & 杭頭弾塑性 \\
\cline { 2 - 6 } & 6 & 1.06 & 1.06 & 0.93 & 0.94 \\
\cline { 2 - 6 } & 9 & 1.16 & 1.43 & 0.95 & 0.94 \\
\hline \multirow{3}{*}{ 同性力 } & 12 & 1.10 & 3.38 & 0.97 & 0.79 \\
\cline { 2 - 6 } & 14 & 1.06 & 1.13 & 0.99 & 0.91 \\
\cline { 2 - 6 } 慣性力 & 6 & 1.11 & 1.16 & 1.04 & 1.06 \\
\cline { 2 - 6 } & 12 & 1.18 & 1.50 & 1.05 & 1.08 \\
\cline { 2 - 6 } & 14 & 1.24 & 8.81 & 1.06 & 1.10 \\
\hline
\end{tabular}

率が発生したことに起因する。

次に、地盤変位が杭頭曲率に及ぼす影響度について分析する。こ こでは慣性力作用の杭頭曲率に対する、動的解析と同方向作用の杭 頭曲率の比率を、杭頭曲率に対する地盤変位の影響度として分析す る。表 4 に杭頭曲率に対する地盤変位の影響度の一覧を示す。同表 で 1.0 を超えている值が、地盤変位の影響度とみることができる。ま ず、告示波に比べて八戸波の方が地盤の応答変位が大きいため（図 27）、表 4 の值が大きく、杭頭曲率に対する地盤変位の影響度は大き いと言える。次に、杭頭弾性条件に比べて杭頭弾塑性条件では表 4 の值が大きくなる傾向が認められる。特に図 28 で示したように、厚 さ $12 \mathrm{~mm} 、 14 \mathrm{~mm}$ の鋼管杭では慣性力のみでは塑性化しないが、地盤 変位が加わることによって塑性化して杭頭曲率がかなり大きくなる ため、表 4 の值が大きくなっている。よって、杭頭の塑性化を考慮 する場合、地盤変位が杭頭曲率応答に及ぼす影響は大きくなる事が 分かる。以上より、杭頭曲率を静的解析により評価する場合には、上 部構造慣性力が支配的な条件であっても、上部構造慣性力に加えて 地盤変位を同位相で考慮した応答変位法を用いることが望ましい。

\section{6 まとめ}

本論文では、杭頭の塑性化に着目した遠心載荷実験のシミュレー ション解析に基づいてパラメトリックスタディを実施し、杭頭の損 傷評価において適切な解析モデルと考慮す心゙き影響因子を明らかに した。具体的な知見を以下に示す。

(1) せん断応力ーひずみ関係の履歴減衰を小ひずみ領域から連続的 に考慮できる材料特性を用いた非線形3D-FEMにより、杭頭の 塑性化を伴う杭基礎建物の遠心振動実験をシミュレーションで きる。

(2) 杭一地盤間のすべり・剥離は上部構造の加速度応答及び杭に生 じる最大曲率にある程度の影響を及ぼすため、解析の精度を高 めるためにはこれらを適切に評価することは重要である。ただ し、杭一地盤間の剥離・すべりの影響は大きくはないため、簡 易な多質点系梁ばねモデルを用いた多入力解析によっても、実 験を概ねシミュレーションできる。

(3) 多質点系梁ばねモデルによる解析的検討から、実験においては 杭頭剛性の変化、及び杭頭部の履歴減衰の両方が影響し、杭頭 に作用する上部構造慣性力が変化することを明らかにした。 よって、杭頭の損傷を適切に評価するためには、杭頭の塑性化 を反映させた上部構造慣性力を設定する必要がある。

(4) 杭頭の塑性化を考慮する場合、地盤変位が杭頭曲率応答に及ぼ す影響は大きくなる。杭頭曲率を静的解析により評価する場合 には、上部構造慣性力が支配的な条件であっても、上部構造慣 性力に加えて地盤変位を同位相で考慮した応答変位法を用いる ことが望ましい。

本論文は遠心載荷実験で対象とした限られた杭基礎建物について の検討であり、実物杭基礎に対して、杭の損傷を考慮した汎用的な 外力の評価方法を提案するまでには至っていない。今後、実物杭基 礎建物を対象としたパラメトリックスタディを進めることで、杭頭 の損傷を考慮した外力の適切な設定方法と簡便で汎用性のある杭の 損傷評価手法の提案に繋げたいと考えている。 


\section{謝辞}

本研究は京都大学防災研究所で実施した遠心載荷実験 5 )に基づい たシミュレーション解析を発展させ、結果をまとめたものです。本 論文で参照させて頂きました実験の実施に際して、京都大学防災研 究所の田村修次准教授には多大なご協力とご指導を頂きました。こ こに記して感謝の意を表します。

\section{参考文献}

1) 日本建築学会近畿支部基礎構造部会, 兵庫県南部地震建築基礎被害調査委 員会: 兵庫県南部地震による建築基礎の被害調査事例報告書, 1996.7.

2) 日本建築学会 : 大会 (東海) 構造部門 (基礎構造) パネルディスカッショ ン資料 基礎構造の地震被害と耐震設計、2012.9.

3) 日本建築学会 : 大会 (中国) 構造部門 (基礎構造) パネルディスカッショ ン資料 大地震時の杭基礎の耐震設計、2008.9.

4) 日本建築学会 : 第8回構造物と地盤の動的相互作用シンポジウム、2006.12.

5) 秀川貴彦, 岸本美季, 柏尚稔, 宮本裕司, 田村修次 : 杭一地盤系の非線形 性を考慮した杭基礎建物の地震応答性状, 日本建築学会構造系論文集, No.661, pp.491-498, 2011.3

6) 宮本裕司, 酒向裕司, 岡安隆史: 杭支持建物の耐震性能評価に関する研究 , 日本建築学会構造系論文集, No.547, pp.59-65, 2001.9.

7) 護雅史, 長谷川正幸, 土方勝一郎：ペンツェンモデルにおける地盤ばねの 剥離を考慮した復元力モデルの検討, 日本建築学会大会学術講演梗概集, B-2, 構造 II , pp.389-390, 1999.9.

8) 松岡正純, 日下部馨,前田幸典: 杭周辺地盤の非線形性を考慮した動的群 杭効果, 日本建築学会大会学術講演梗概集, B-2, 構造 II, pp.367-368, 2000.9.

9) Makoto Kimura and Feng Zhang: Seismic evaluations of pile foundations with three different methods based on three-dimensional elasto-plastic finite element analysis, Soil and foundations, Vol.40, No.5, pp.113-132, 2000.10.

10）周友吴, 時松孝次, 吉田洋之, 鈴木比呂子, 貫井泰 : 大型振動台実験にお ける地盤一杭一構造物系の3次元動的挙動に関する解析的検討, 日本建築 学会構造系論文集, No.677, pp.1079-1088, 2012.7.

11) 石崎定幸, 真島正人, 長尾俊晶, 船原秀樹, 青島一樹 : 杭頭半剛接合工法 を採用した杭基礎建物と地盤の模型振動実験, 日本建築学会構造系論文集 , No.602, pp.171-177, 2006.4.

12) 田村修次, 肥田剛典: 大型せん断土槽を用いた液状化実験における RC杭
の破壊が構造物挙動に及ぼす影響, 日本建築学会構造系論文集, No.635, pp.91-96, 2009.1.

13) 酒向裕司, 宮本裕司: 変動軸力を考慮した杭基礎の地震応答に関する解析 的検討, 日本建築学会構造系論文集, No.523, pp.79-86, 1999.9.

14）長江拓也, 内村均, 小林恒一, 吉田望, 林静雄 : 変形性能に優れた鉄筋二 ンクリート杭に支持される建物の地震応答解析, 日本建築学会構造系論文 集, No.555, pp.107-114, 2002.5.

15) 平塚高弘, 平石久廣, 小林正人, 大場航, 齋藤元嗣, 渡辺一弘 : 杭頭接合条 件が建物の地震応答性状に与える影響に関する研究、日本建築学会構造系 論文集、No.649、pp.625-633,2010.3.

16）引田真規子, 酒向裕司, 宮本裕司: 基礎梁・杭と杭周地盤ばねの非線形性 が杭基礎構造物の地震応答に与える影響, 日本建築学会構造系論文集, No.641, pp.1241-1248, 2009.7

17) LS-DYNA Version 971 Users Manual Volume I II

18）間瀬達也, 橋口公一, 中井正一, 土方勝一郎, 杉山達也, 柳下文雄 : 下負荷 面モデルを用いた単杭の水平挙動の3次元弾塑性解析, 日本建築学会構造 系論文集, No.626, pp575-582, 2008.4.

19) Fumio Tatsuoka, Toshio Iwasaki, Shinji Fukushima and Hideo Suda : Stress conditions and stress histories affecting shear modulus and damping of sand under cyclic loading, soils and foundations, Vol.19, No.2, pp.29-43, 1979.6.

20) 田中忠次, 鵜飼恵三, 河邑眞, 坂上最一, 大津宏康 : 地盤の三次元弾塑性 有限要素解析, 丸善株式会社, p60, 1996.3.

21）福武毅芳: 土の多方向繰返しせん断特性を考慮した地盤構造物系の三次 元液状化解析に関寸る研究, 名古屋工業大学博士論文, 1997.9.

22) 地盤工学会: 地盤工学ハンドブック,pp.85-86, 1999.3 .

23) 宮本裕司, 福岡篤信, 安達直人, 酒向裕司: 液状化地盤における杭基礎の 地震時杭応力に関する研究 杭基礎の遠心模型実験と解析的検討, 日本建 築学会構造系論文集, No.482, pp.53-62, 1996.4.

24）清田芳治, 萩原庸嘉, 田村英雄 : 硅砂6号の動的変形特性に関寸る研究, 第 30 回土質工学研究発表会, pp.851-852, 1995.7 .

25) 木村匠, 社本康広, 松井和幸, 真野英之, 護雅史, 中井正一: 杭基礎構造物 の耐震性に及ぼす基礎梁の剛性の影響, 日本建築学会構造系論文集, No.618, pp.41-48, 2007.8.

26) 構造計画研究所 : RESP - F3T 利用者マニュアル, 2010.5.

27) 日本建築学会: 建物と地盤の動的相互作用を考慮した応答解析と耐震設計, 2006.2.

28）日本建築学会 : 基礎構造設計指針, 2001.10。 